\title{
HAEMACYTOLOGICAL CHANGES IN HOG CHOLERA
}

I. Observations on the "Substantia Granulo-Filamentosa" in red blood cell-Reticulocytes

\author{
S. Ishit, S. Watnabe and Y. Muvra \\ (From the Veterinary Laboratory of the Ministry of Agricullure \\ and Forestry, Nishigahara, Tokyo)
}

(Received for publication February 18, 1935)

INTRODUCTION

The existence of some vital-stained substances in normal red blood-corpuscles of the horse, cattle, sheep, swine, cat, dog and rabbit was demonstrated by Natcheff Bojan in 1931. Further observations on such substances in red blood-corpuscles of several domestic animals, however, have not been made by others.

According to the original description of the first observer, it is concluded that such a substance must be a protoplasmatic residue derived during the embryonal course of erythrocytes, because it is generally observed in the circulating blood examined in the course of plastic anaemia.

Moreover, the same inclination to the appearance of this substance in blood-stream is observed in several animals, more in the younger animals than in the older: percentages of all red blood-corpuscles found are following: $0.2-0.9 \%$ in adult dogs while $72 \%$ in puppies, $0.3-0.7 \%$ in adult swine while $1.1-13.8 \%$ in sucklings of $2-3$ months, $0.3 \%$ in adult cats while $40 \%$ in foetal cats and $30-80 \%$ in suckling rabbits.

These observations are limited to the normal circulating blood and the demonstration of such cells in blood-stream of some diseased animals seems to be rare.

Thus, we attempted some studies on this subject to demonsrate any change of cells in circulating blood of the swine affected with 
hog cholera in which red blood-corpuscles usually are much reduced.

Judging from our experimental results, the numerical observations of erythrocytes containing "Substantia Granulo-Filamentosa" in circulating blood are considered to be worthy for the determination of the prognosis in cases of hog cholera and for its haemacytological differentiation from other bacillary diseases.

\section{Experimental Methods}

(1) Varieties of the erythrocytes containing "Substantia Granulo-Filamentosa". Three types are found in blood-stream of swine and can be conveniently differentiated by the shape of the granule in stained preparations:

Type I containing coarse granules, Type II containing middlesized, reticular granules and Type III containing small granules along the periphery of cell-body.

(2) The super-vital staining with a saline solution of brilliant cresylblau was employed.

(3) To make a differential count of above three types of erythrocytes, Max-Levy's haemacytometer was used. And the relative number of these three types was found by counting at least 1.000 erythrocytes. If any of the three types was not found, another $1.000-2.000$ crythrocytes were counted.

\section{RESUlTS OF EXPERIMENTS}

(I) Healthy swine.

10 healthy swine of different ages were strictly examined and the following results were obtained:

\begin{tabular}{|c|c|c|c|c|c|c|c|c|c|c|}
\hline No. of swine & 1 & 2 & 3 & 4 & 5 & 6 & 7 & 8 & 9 & 10 \\
\hline $\begin{array}{l}\text { Numbers of Erythlocytes } \\
\text { (in } 1 \text { c.mm) }\end{array}$ & 694 & 664 & 723 & 712 & 594 & 643 & 754 & 642 & 568 & 684 \\
\hline $\begin{array}{l}\text { Varieties of reticulocytes } \\
\text { (in 1.000 Erythro- } \\
\text { cytes) }\end{array}$ & $\begin{array}{c}2 \\
7 \\
13\end{array}$ & $\begin{array}{l}1 \\
1 \\
2\end{array}$ & $\begin{array}{l}2 \\
4 \\
6\end{array}$ & $\begin{array}{l}1 \\
1 \\
2\end{array}$ & $\begin{array}{l}0 \\
3 \\
2\end{array}$ & $\begin{array}{l}1 \\
1 \\
7\end{array}$ & $\begin{array}{l}1 \\
2 \\
3\end{array}$ & $\begin{array}{l}3 \\
5 \\
7\end{array}$ & $\mid \begin{array}{c}7 \\
11 \\
14\end{array}$ & $\begin{array}{l}1 \\
3 \\
5\end{array}$ \\
\hline Haemoglobin (Sahli) & 74 & 76 & 74 & 77 & 73 & 69 & 84 & 75 & 60 & 74 \\
\hline Numbers of months after birth & 2 & 18 & 20 & 10 & 8 & 8 & 7 & 7 & 6 & 8 \\
\hline
\end{tabular}




\begin{tabular}{|c|c|c|c|c|c|c|c|c|c|c|c|c|c|}
\hline 유 궁 & $\underset{\infty}{0}$ & omo & $\infty$ & & & & & & & & & & \\
\hline$\stackrel{\circ}{\circ}$ & న & $c \pi$ & $尺$ & & & & & & & & & & \\
\hline$\dddot{m}$ & ন্ড & $\pi \cos \theta$ & $\infty$ & & & & & & & & & & \\
\hline$a$ & 芯 & $O H$ in & 8 & & & & & & & & & & \\
\hline $\begin{array}{l}0 \\
\infty\end{array}$ & $\infty_{\infty}^{\infty}$ & 000 & ร & & & & & & & & & & \\
\hline 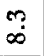 & $\bigotimes_{\infty}$ & $\tan \pi$ & $\infty$ & & & & & & & $\vec{a}$ & id & trin & $R$ \\
\hline$\stackrel{\circ}{\sim}$ & $\underset{\infty}{\infty}$ & $00 \mathrm{in}$ & $\varnothing$ & & & & & & & 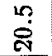 & \% & $\pi A d$ & $m$ \\
\hline$\stackrel{m}{n}$ & 范 & trma & $\approx$ & & & & & & & สิ & 늉 & ODN & $\stackrel{2}{i}$ \\
\hline N & 柋 & $=-r e v$ & $\stackrel{\infty}{2}$ & & $\stackrel{\infty}{\infty}$ & तु & $O H C$ & $\stackrel{\infty}{\infty}$ & & 20 & हु & HOH & $\stackrel{\infty}{N}$ \\
\hline $\begin{array}{l}0 \\
0 \\
0\end{array}$ & $\underset{\infty}{\infty}$ & $N \operatorname{los} 0$ & $\vec{\infty}$ & & 苂 & $\stackrel{2}{\pi}$ & crom & $N$ & & $\begin{array}{l}\infty \\
\infty\end{array}$ & $\begin{array}{l}\text { in } \\
\text { in }\end{array}$ & $v \in H$ & ร \\
\hline$\ddot{c}$ & $\stackrel{\infty}{\infty}$ & 매 & $\infty$ & & $\approx$ & 点 & $0=\pi$ & $\bar{a}$ & & $\stackrel{2}{\sim}$ & รั & orros & ॠै \\
\hline 6 & $\underset{\Sigma}{\mathcal{N}}$ & $\operatorname{mon}$ & 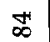 & & n? & 胥 & $=-1-1$ & $\underset{\infty}{\infty}$ & & $\stackrel{10}{\Omega}$ & 苞 & $m-m$ & $\infty$ \\
\hline$\ddot{3}$ & $\underset{N}{\mathbb{Z}}$ & orin & $\infty$ & & 象 & 出 & $\theta=c$ & $g$ & & $\approx$ & $\mathbb{\infty}$ & aros & 10 \\
\hline in & 今ू & Nrtin & $\infty$ & $\Xi$ & $m$ & $\stackrel{\infty}{10}$ & orr & $\infty$ & $\bar{F}$ & ? & $\begin{array}{l}\infty \\
\infty \\
0 \\
i n\end{array}$ & Fin & R \\
\hline$\underset{+}{\mathscr{4}}$ & $\stackrel{\infty}{\infty}$ & orvin & $\mathscr{\infty}$ & 号 & $\mathbb{J}_{-1}^{n}$ & $\infty$ & $O H+$ & \& & 言 & $\mathscr{7}$ & 象 & noun & $R$ \\
\hline$\stackrel{m}{+}$ & $\stackrel{\substack{\sharp \\
\sim}}{N}$ & tien in & gू & & $\mathbb{I}$ & 㖞 & HTH & $\infty$ & & in & 苟 & HON & 8 \\
\hline 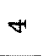 & $\stackrel{0}{N}$ & 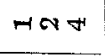 & $\stackrel{ }{0}$ & & 20 & 哭 & orim & $\varnothing$ & & $\stackrel{n}{-10}$ & वै & $\operatorname{tin} 10$ & $\stackrel{\infty}{N}$ \\
\hline m. & 8 & $m-10$ & 5 & & $\Rightarrow$ & ণ్ని & -OH & $\infty$ & & 旾 & 总 & $O H-1$ & $N$ \\
\hline$m$ & 8 & mNO & 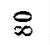 & & $\begin{array}{l}n \\
c \\
c\end{array}$ & in & 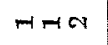 & హ゙ & & $\underset{I}{ت}$ & 윰 & Hom & $\because$ \\
\hline $\begin{array}{c}0 \\
\dot{\gamma}\end{array}$ & i & mas & $\mathbb{N}$ & & $\cong$ & 怘 & matis & 闹 & & 年 & $\frac{0}{6}$ & $\exists \underset{\sim}{\sim} \approx$ & 8 \\
\hline 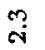 & ్ㅇㅇ & N๐O & 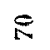 & & $\stackrel{2}{=}$ & 윤 & $0-1-1$ & I & & 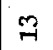 & ס్ & 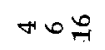 & $\cong$ \\
\hline$\infty$ & 㤩 & and & 离 & & $\Rightarrow$ & D̆ & Nor & 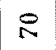 & & 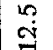 & \% & $O ت \pi N$ & 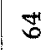 \\
\hline 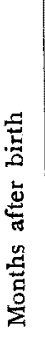 & 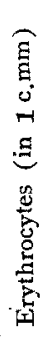 & 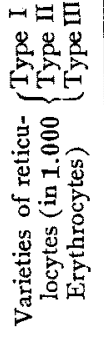 & 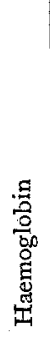 & & 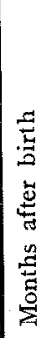 & 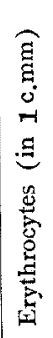 & 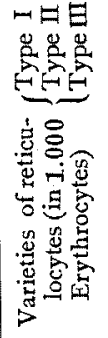 & 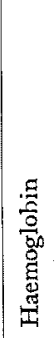 & & 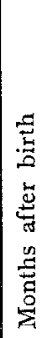 & 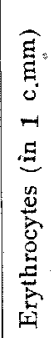 & 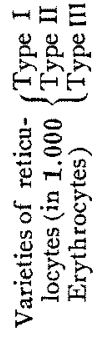 & 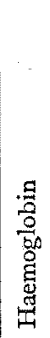 \\
\hline
\end{tabular}


As shown in the above table, the number of erythrocytes belonging to the three types was large in the young animals for a definite period after birth while lower in the aged ones, even in a 20-month old animal; the total number of such erythrocytes were about 12 .

Although swine of different ages were not yet examined in a number of cases sufficient to make a definite statement for each type of red blood-cells, it is reasonable to consider that such special red blood-corpuscles are found in circulating blood of the healthy swine for a long time after birth. And the average number of erythrocytes found in swine was 6.68 millions per c.mm-the maximum being 7.54 while the minimum being 5.68 . Moreover, the counts of the red blood-cells belonging to type III were usually higher than those of other types in normal condition.

Then, we attempted further successive blood examinations in three groups of healthy swine of different ages.

The results obtained are as follows:

As shown in the above table, the total number of red bloodcells belonging to three types in circulating blood gradually decreased in proportion to the number of months after birth. However, the appearance of such red blood-corpuseles in bloodstream will possibly be dependable upon the difference of individual constitution beside the age.

Of the three types, the counts of type III were usually more numerous than the other two, as seen in the former experiment, and the percentage of the total numbers was $0.2-4.0$, varying for a period of $3-20$ months after birth.

(2) The swine affected with hog cholera.

Aithough changes occurring in the blood of the animal affected with hog cholera were studied by several authors, descriptions concerning the reticulocytes seem to be very rare. Thus, the first attempt was made to determine whether any changes in them is recognizable or not. For this purpose eight healthy swine of different ages were artificially infected by inoculating the virus, and blood examinations were successively made in the course of the disease.

The result of these examinations is tabulated as follows: 
Case 1 (about 10 months after birth) $\dagger$

\begin{tabular}{|c|c|c|c|c|c|c|c|c|}
\hline Date & $16 / 10$ & $19 / 10$ & $21 / 10$ & \multirow{5}{*}{ 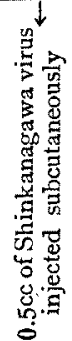 } & $24^{\prime} 10$ & $27 / 10$ & $31 / 10$ & $2 / 11$ \\
\hline 'Temperature & - & - & 39.1 & & 39.5 & 40.4 & 40.7 & 40.3 \\
\hline Erythrocytes & 612 & 568 & 512 & & 524 & 524 & 470 & 405 \\
\hline $\begin{array}{l}\text { Varieties of } \\
\text { reticulocytes } \\
\text { (in } 1.000 \\
\text { Erythrocytes }\end{array}\left\{\begin{array}{l}\text { Type I } \\
\text { Type II } \\
\text { Type III }\end{array}\right.$ & - & $\begin{array}{c}7 \\
11 \\
4\end{array}$ & $\begin{array}{c}5 \\
13 \\
14\end{array}$ & & $\begin{array}{l}2 \\
4 \\
4\end{array}$ & $\begin{array}{l}2 \\
2 \\
4\end{array}$ & $\begin{array}{l}0 \\
0 \\
0\end{array}$ & $\begin{array}{l}0 \\
0 \\
0\end{array}$ \\
\hline Haemoglobin & 65 & 60 & 57 & & 64 & 56 & 59 & 43 \\
\hline
\end{tabular}

Case 2 (about 10 months after birth) $\dagger$

\begin{tabular}{|c|c|c|c|c|c|c|c|}
\hline Date & $15 / 9$ & $19 / 9$ & $21 / 9$ & \multirow{5}{*}{ 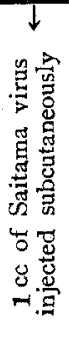 } & $23 / 9$ & $25 / 9$ & $26 / 9$ \\
\hline Temperature & - & 39.0 & 39.2 & & 39.9 & 41.2 & 40.7 \\
\hline Erythrocytes & 684 & 680 & 662 & & - & - & 878 \\
\hline $\begin{array}{l}\text { Varieties of } \\
\text { reticulocytes } \\
\text { (in } 1.000 \\
\text { Erythrocytes) }\end{array}\left\{\begin{array}{l}\text { Type I } \\
\text { Type II } \\
\text { Type III }\end{array}\right.$ & $\begin{array}{l}1 \\
3 \\
5\end{array}$ & $\begin{array}{l}3 \\
6 \\
2\end{array}$ & $\begin{array}{l}2 \\
3 \\
4\end{array}$ & & - & - & $\begin{array}{l}0 \\
0 \\
0\end{array}$ \\
\hline Haemoglobin & 79 & 73 & 77 & & - & - & 100 \\
\hline
\end{tabular}

Case 3 (about 8 months after birth) $\dagger$

\begin{tabular}{|c|c|c|c|c|c|c|c|c|c|}
\hline Date & $8 / 8$ & $10 / 8$ & $12 / 8$ & \multirow{5}{*}{ 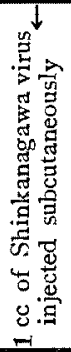 } & $15 / 8$ & $17 / 8$ & $19 / 8$ & $22 / 8$ & $24 / 8$ \\
\hline Temperature & 一 & - & 39.5 & & 40.0 & 40.5 & 41.2 & 41.3 & 41.0 \\
\hline Erythrocytes & 552 & 582 & 648 & & 640 & 592 & 608 & 460 & 512 \\
\hline $\begin{array}{l}\text { Varieties of } \\
\text { reticulocytes } \\
\text { (in 1.000 } \\
\text { Erythrocytes) }\end{array}\left\{\begin{array}{l}\text { Type I } \\
\text { Type II } \\
\text { Type III }\end{array}\right.$ & $\begin{array}{l}2 \\
5 \\
5\end{array}$ & $\begin{array}{l}1 \\
1 \\
2\end{array}$ & $\begin{array}{l}0 \\
3 \\
2\end{array}$ & & $\begin{array}{l}0 \\
0 \\
1\end{array}$ & $\begin{array}{l}0 \\
1 \\
2\end{array}$ & $\begin{array}{l}0 \\
0 \\
\mathbf{1}\end{array}$ & $\begin{array}{l}0 \\
1 \\
0\end{array}$ & $\begin{array}{l}0 \\
0 \\
0\end{array}$ \\
\hline Haemoglobin & 66 & 66 & 73 & & 76 & 60 & 64 & 45 & 46 \\
\hline
\end{tabular}

Case 4 (about 8 months after birth) $\dagger$

\begin{tabular}{|c|c|c|c|c|c|c|c|c|c|}
\hline Date & $19 / 10$ & $21 / 10$ & $24 / 10$ & $27 / 10$ & $30 / 10$ & $31 / 10$ & $2 / 11$ & $4 / 11$ & $7 / 11$ \\
\hline Temperature & - & 39.0 & 39.4 & 39.4 & \multirow{4}{*}{ 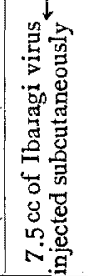 } & 40.8 & 40.5 & 4.06 & 40.8 \\
\hline Erythrocytes & 632 & 648 & 740 & 636 & & 614 & 524 & 612 & 484 \\
\hline $\begin{array}{l}\text { Varieties of } \\
\text { reticutocytes } \\
\text { (in } 1.000 \\
\text { Erythrocytes) }\end{array}\left\{\begin{array}{l}\text { Type I } \\
\text { Type II } \\
\text { Type III }\end{array}\right.$ & $\begin{array}{l}8 \\
3 \\
3\end{array}$ & $\begin{array}{l}4 \\
8 \\
2\end{array}$ & $\begin{array}{l}14 \\
12 \\
10\end{array}$ & $\begin{array}{l}2 \\
6 \\
2\end{array}$ & & $\begin{array}{l}0 \\
0 \\
1\end{array}$ & $\begin{array}{l}0 \\
0 \\
0\end{array}$ & $\begin{array}{l}0 \\
0 \\
0\end{array}$ & $\begin{array}{l}0 \\
0 \\
0\end{array}$ \\
\hline Haemoglobin & 71 & 66 & 83 & 68 & & 63 & 52 & 64 & 49 \\
\hline
\end{tabular}


Case 5 (about 8 months after birth) slaughte ed

\begin{tabular}{|c|c|c|c|c|c|c|c|c|c|c|c|c|c|}
\hline \multicolumn{2}{|l|}{ Date } & $|10 / 7|$ & $13 / 7$ & $15 / 7$ & $18 / 7$ & $20 / 7$ & \multirow{7}{*}{ 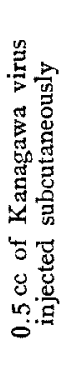 } & $22 / 7$ & $25 / 7$ & $27 / 7$ & $29 / 7$ & $1 / 8$ & $3 / 8$ \\
\hline \multicolumn{2}{|c|}{ Temperature } & 39.0 & 3 & 38.8 & 38.9 & 38.7 & & 39.7 & 40.5 & 39.8 & 41.1 & 40.9 & - \\
\hline \multicolumn{2}{|c|}{ Erythrocytes } & 552 & 526 & 580 & 558 & 566 & & 564 & 526 & 580 & 504 & 486 & 540 \\
\hline \multirow{3}{*}{$\begin{array}{l}\text { Varieties } \\
\text { of reti- } \\
\text { culocytes } \\
\text { (in } 1.000 \\
\text { Erythro- } \\
\text { cytes) }\end{array}$} & & 9 & 7 & 3 & 1 & 1 & & 4 & 0 & 0 & 0 & $\mathbf{0}$ & 0 \\
\hline & el & 26 & 18 & 9 & 7 & 2 & & 1 & 1 & 0 & 0 & 0 & 0 \\
\hline & (Type & 30 & 16 & 11 & 5 & 4 & & 0 & 0 & 0 & 1 & 0 & 0 \\
\hline \multicolumn{2}{|c|}{ Haemoglobin } & 76 & 78 & 76 & 72 & 73 & & 75 & 66 & 73 & 73 & 72 & 73 \\
\hline
\end{tabular}

Case 6 (about 8 months after birth) $\dagger$

\begin{tabular}{|c|c|c|c|c|c|c|c|c|c|c|}
\hline Date & $01 / 7$ & $13 / 7$ & $15 / 7$ & 18.7 & $20 / 7$ & \multirow{7}{*}{ 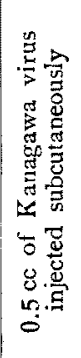 } & $22 / 7$ & $25 / 7$ & $27 / 7$ & $29 / 7$ \\
\hline Temperature & - & 39.0 & 38.9 & 38.9 & 39.1 & & 39.7 & 41.4 & 41.1 & 41.0 \\
\hline Erythrocytes & 756 & 742 & 762 & 765 & 776 & & 776 & 684 & 748 & 556 \\
\hline \multirow{3}{*}{$\begin{array}{c}\text { Varieties of re- } \\
\text { (iculocytes } \\
\text { (in } 1.000 \\
\text { Erythrocytes) }\end{array}\left\{\begin{array}{l}\text { Type I } \\
\text { Type II } \\
\text { Type III }\end{array}\right.$} & 4 & 2 & 1 & 1 & 3 & & 2 & 0 & 0 & 0 \\
\hline & 15 & 7 & 2 & 2 & 3 & & 1 & 0 & 0 & 0 \\
\hline & 7 & 5 & 2 & 5 & 2 & & 0 & 0 & 1 & 0 \\
\hline Haemoglobin & 86 & 85 & 85 & 90 & 39 & & 87 & 81 & 88 & 76 \\
\hline
\end{tabular}

As seen the above table, the counts of reticulocytes gradually decreased in accordance with the appearance of characteristic symptoms in hog cholera and they were scanty or absent in the blood-stream when the diseased animal was feverish. Of course, the counts of whole red blood-corpuscles were also reduced in the same condition.

However, in Cases 7 and 8 which survived, different numerical changes of reticulocytes were observed; the gradual diminution of cells was found at the feverish stage, but a sudden increase over the counts before injection of the virus was demonstrated in the case gradually recovered.

In all the cases, the numerical ratio of each type of the reticulocytes was almost constantly observed, Type I and II disappearing earlier than Type III.

(3) The swine vaccinated against hog cholera. 


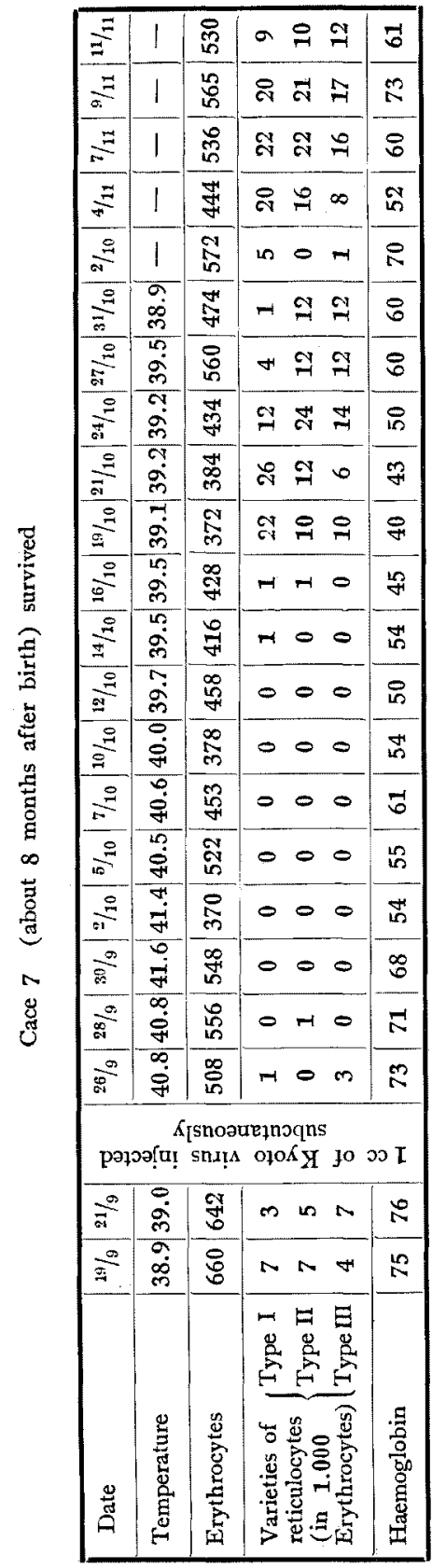

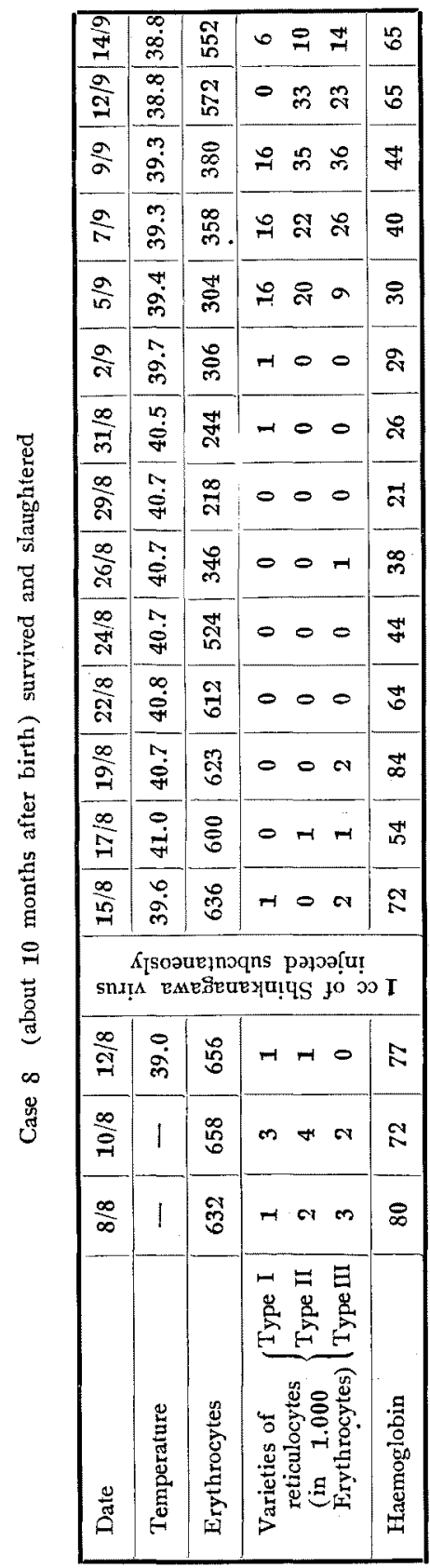


Basing upon the observations above described, another experiment was carried out on six swine which received the injection of hog cholera vaccine for the protective purpose.

The results obtained are tabulated as follows:

Case 1 (10 months after birth)

\begin{tabular}{|c|c|c|c|c|c|c|c|c|}
\hline Date & $15 / 2$ & \multirow{7}{*}{ 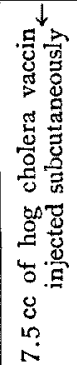 } & $17 / 2$ & $20 / 2$ & $22 / 2$ & $24 / 2$ & $27 / 2$ & $1 / 3$ \\
\hline Temperature & 38.7 & & 38.8 & 38.7 & 38.6 & 38.5 & 38.5 & 38.8 \\
\hline Erythrocytes & 958 & & 888 & 724 & 788 & 778 & 812 & 844 \\
\hline \multirow{3}{*}{$\begin{array}{c}\text { Varieties of re- } \\
\text { ticulocytes } \\
\text { (in 1.000 } \\
\text { Erythrocytes) }\end{array}\left\{\begin{array}{l}\text { Type I } \\
\text { Type II } \\
\text { Type III }\end{array}\right.$} & 1 & & 0 & 0 & 2 & 0 & 2 & 1 \\
\hline & 2 & & 0 & 0 & 0 & 0 & 0 & 3 \\
\hline & 3 & & 1 & 1 & 0 & $\mathbf{1}$ & 3 & 3 \\
\hline Haemoglobin & 98 & & 80 & 74 & 81 & 78 & 80 & 88 \\
\hline
\end{tabular}

Case 2 (10 months after birth)

\begin{tabular}{|c|c|c|c|c|c|c|c|c|c|c|c|}
\hline Date & $2 / 2$ & \multirow{7}{*}{ 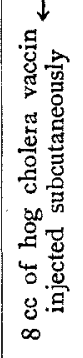 } & $5 / 2$ & $7 / 2$ & $9 / 2$ & $11 / 2$ & $14 / 2$ & $16 / 2$ & $19 / 2$ & $21 / 2$ & $23 / 2$ \\
\hline Temperature & 39.5 & & 39.6 & 39.6 & 39.5 & 39.2 & 39.1 & 38.8 & 38.6 & 38.6 & 38.9 \\
\hline Exythrocytes & 594 & & 638 & 600 & 667 & 664 & 728 & 638 & 624 & 582 & 536 \\
\hline Varieties of re- $\int^{\text {Type }}$ & 0 & & 1 & $\mathbf{1}$ & 0 & 5 & 2 & 1 & 0 & 0 & 0 \\
\hline $\begin{array}{l}\text { ticulocytes } \\
\text { (in } 1.000\end{array} \quad$ Ty & 3 & & 2 & 2 & 0 & 3 & 3 & 3 & 1 & 0 & 1 \\
\hline Eryth rocytes Type III & 2 & & 3 & 5 & 1 & 9 & 3 & 4 & 4 & 3 & 1 \\
\hline Haemoglobin & 73 & & 84 & 80 & 83 & 80 & 80 & 71 & 69 & 75 & 64 \\
\hline
\end{tabular}

Case 3 (10 months after birth)

\begin{tabular}{|c|c|c|c|c|c|c|c|c|c|c|c|}
\hline Date & $2 / 2 \mid$ & \multirow{7}{*}{ 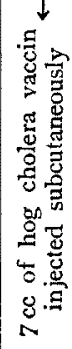 } & $5 / 2$ & $7 / 2$ & $9 / 2$ & $\mid 12 / 2$ & $14 / 2$ & $16 / 2$ & $19 / 2$ & $21 / 2$ & 23.2 \\
\hline Temperature & - & & 38.8 & 39.5 & 39.2 & 39.7 & 38.6 & 38.6 & 38.6 & 38.8 & 3.89 \\
\hline Erythrocytes & 712 & & 792 & 836 & 740 & 680 & 678 & 664 & 656 & 721 & 640 \\
\hline \multirow{3}{*}{$\begin{array}{c}\text { Varieties of re- } \\
\text { ticulocytes } \\
\text { (in } 1.000 \\
\text { Erythrocytes) }\end{array}\left\{\begin{array}{l}\text { Type I } \\
\text { Type II } \\
\text { Type II! }\end{array}\right.$} & 1 & & 1 & 1 & 3 & 2 & 0 & 0 & 0 & 0 & 0 \\
\hline & 1 & & 1 & 2 & 2 & 3 & 1 & 0 & 0 & 0 & 0 \\
\hline & 2 & & 2 & 1 & 1 & 3 & 1 & 0 & 0 & 0 & 0 \\
\hline Haemoglobin & 77 & & 93 & 105 & 85 & 81 & 84 & 78 & 72 & 95 & 65 \\
\hline
\end{tabular}


Case 4 (12 months after birth)

\begin{tabular}{|c|c|c|c|c|c|c|c|c|c|c|}
\hline Date & $19 / 12$ & $21 / 12$ & $23 / 12$ & \multirow{7}{*}{ 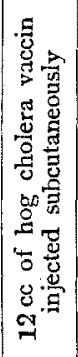 } & $26 / 12$ & $28 / 12$ & $30 / 12$ & $4 / 1$ & $6 / 1$ & $8 / 1$ \\
\hline Temperature & - & - & 88.5 & & 38.8 & 38.6 & 38.6 & 39.1 & 38.9 & 38.8 \\
\hline Erythrocytes & 596 & 554 & 548 & & 620 & 586 & 576 & 552 & 512 & 542 \\
\hline \multirow{3}{*}{$\begin{array}{c}\text { Varieties of re- } \\
\text { ticulocytes } \\
\text { (in } 1.000 \\
\text { Erythrocytes) }\end{array}\left\{\begin{array}{l}\text { Type I } \\
\text { Type II } \\
\text { Type III }\end{array}\right.$} & 0 & 1 & 0 & & 0 & 一 & 1 & 1 & 0 & 0 \\
\hline & 1 & 1 & 0 & & 0 & 一 & 1 & 1 & 0 & 1 \\
\hline & 0 & 0 & 1 & & 1 & - & 0 & 0 & 1 & 0 \\
\hline Haemoglobin & 74 & 65 & 72 & & 84 & 73 & 62 & 68 & 56 & 59 \\
\hline
\end{tabular}

Case 5 (10 months after birth)

\begin{tabular}{|c|c|c|c|c|c|c|c|c|}
\hline Date & $15 / 2$ & \multirow{7}{*}{ 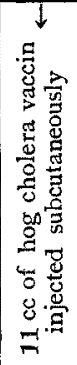 } & $17 / 2$ & $20 / 2$ & $22 / 2$ & $24 / 2$ & $27 / 2$ & $1 / 3$ \\
\hline Tamperature & 38.5 & & 38.9 & 38.8 & 38.7 & 38.5 & 38.7 & 38.9 \\
\hline Erythrocytes & 922 & & 834 & 698 & 750 & 828 & 624 & 736 \\
\hline Varieties of re- Type I $^{\text {Types }}$ & 0 & & 0 & 0 & 4 & 1 & 2 & 1 \\
\hline $\begin{array}{l}\text { ticulocytes } \\
\text { (in } 1.000\end{array}$ Type II & 0 & & 0 & 0 & 2 & 2 & 3 & 2 \\
\hline Erythrocytes) (Type III & 1 & & 0 & 2 & 0 & 2 & 1 & 4 \\
\hline Haemoglobin & 94 & & 84 & 69 & 68 & 59 & 83 & 90 \\
\hline
\end{tabular}

Case 6 (10 months after birth)

\begin{tabular}{|c|c|c|c|c|c|c|c|c|}
\hline Date & $15 / 2$ & \multirow{7}{*}{ 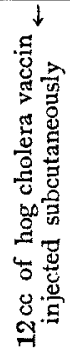 } & $17 / 2$ & $20 / 2$ & $22 / 2$ & $24 / 2$ & $27 / 2$ & $1 / 3$ \\
\hline Temperature & 38.6 & & 39.0 & 38.8 & 38.8 & 38.5 & 38.6 & 38.5 \\
\hline Erythrocytes & 882 & & 798 & 792 & 876 & 932 & 900 & 868 \\
\hline Varieties of re- 1 Type $I$ & 0 & & 0 & $\mathbf{1}$ & 0 & 1 & 1 & 2 \\
\hline ticulocytes $\quad$ Type II & 1 & & 0 & 0 & $\mathbf{0}$ & 2 & 1 & 2 \\
\hline Erythrocytes) Type III & 1 & & 1 & 1 & 1 & 2 & 1 & 2 \\
\hline Haemoglobin & 87 & & 71 & 75 & 82 & 108 & 84 & 84 \\
\hline
\end{tabular}

From the summarized observations of the five cases, no numerical changes in each type of reticulocytes were demonstrated in circulating blood of the swine inoculated with an attenuated hog cholera virus, compared with the counts of such cells before the vaccination. 
On the contrary, in only one case (Case 3) which received the injection of an incompletely attenuated virus without fever, scarcely äny type of reticulocytes was demontrated in bloodstream, but when survived plenty of those cells appeared, Types I and II earlier than Type III.

Thus, it may be observed from these experiments that the injection of the attenuated virus used in practice, did not result in the disappearance of reticulocytes in circulating blood.

(4) Swine affected with swine plague or swine erysipelas.

So far in swine affected with swine plague or swine erysipelas the histological examination has not yet been carried out of reticulocytes in circulating blood. Thus, attempts were made in a sufficient number of cases definitely to differentiate types of reticulocytes as shown in following tables:

\section{A. Swine Plague}

Case 1 (12 months after birth) Natural infection $(\uparrow)$

\begin{tabular}{|c|c|c|}
\hline Date & $26 / 2$ & $29 / 2$ \\
\hline Temperature & 41.2 & 40.5 \\
\hline Erythrocytes & 522 & 508 \\
\hline $\begin{array}{c}\text { Varieties of } \mathrm{R} \\
\text { (in } 1.000 \\
\text { Erythrocytes) }\end{array}\left\{\begin{array}{l}\text { Type I } \\
\text { Type II } \\
\text { Type III }\end{array}\right.$ & $\begin{array}{l}8 \\
3 \\
2\end{array}$ & $\begin{array}{l}9 \\
7 \\
9\end{array}$ \\
\hline Haemoglobin & 49 & 46 \\
\hline Leucocytes & 57.000 & 59.700 \\
\hline
\end{tabular}

Case 2 (15 months after birth) Natural infection $(\dagger)$

\begin{tabular}{|c|c|c|}
\hline Date & $1 / 3$ & $2 / 3$ \\
\hline Temperature & 41.5 & 40.9 \\
\hline Erythrocytes & 506 & 521 \\
\hline $\begin{array}{l}\text { Varieties of R. } \\
\quad \text { (in 1.000 } \\
\text { Erythrocytes) }\end{array}\left\{\begin{array}{l}\text { Type I } \\
\text { Type II } \\
\text { Type III }\end{array}\right.$ & $\begin{array}{l}3 \\
5 \\
6\end{array}$ & $\begin{array}{l}1 \\
8 \\
10\end{array}$ \\
\hline Haemoglobin & 46 & 47 \\
\hline Leucocytes & 28.000 & 36.000 \\
\hline
\end{tabular}

Case 3 (12 months after birth)

Artifical infection by the method of pneumoinjection (slaughtered)

\begin{tabular}{|c|c|c|c|c|c|}
\hline Date & & $6 / 11$ & $10 / 11$ & $13 / 11$ & $15 / 11$ \\
\hline Temperature & & 38.3 & 39.4 & 39.9 & 39.9 \\
\hline $\begin{array}{l}\text { Varieties of } \mathrm{R} \text {. } \\
\quad \text { (in } 1.000 \\
\text { Erythrocytes) }\end{array}$ & $\begin{array}{ll}\text { Type } & \text { I } \\
\text { Type } & \text { II } \\
\text { Type } & \text { III }\end{array}$ & $\begin{array}{l}1 \\
2 \\
3\end{array}$ & $\begin{array}{l}1 \\
4 \\
3\end{array}$ & $\begin{array}{l}\mathbf{1} \\
2 \\
5\end{array}$ & $\begin{array}{l}2 \\
1 \\
5\end{array}$ \\
\hline
\end{tabular}


Case 4 (12 months after birth)

Artificial infection by the method of pneumoinjection (slaughtered)

\begin{tabular}{|c|c|c|c|c|c|}
\hline Date & & $6 / 11$ & $10 / 11$ & $18 / 11$ & $15 / 11$ \\
\hline Temperature & & 38.7 & 38.3 & 39.8 & 39.6 \\
\hline $\begin{array}{l}\text { Varielies of } \mathbf{R} \text {. } \\
\quad \text { (in } 1.000 \\
\text { Erythrocytes) }\end{array}$ & $\left\{\begin{array}{l}\text { Type I } \\
\text { Type II. } \\
\text { Type III }\end{array}\right.$ & $\begin{array}{l}1 \\
2 \\
3\end{array}$ & $\begin{array}{l}1 \\
4 \\
2\end{array}$ & $\begin{array}{l}3 \\
4 \\
7\end{array}$ & $\begin{array}{l}3 \\
2 \\
7\end{array}$ \\
\hline
\end{tabular}

B. Swine Erysipelas

Case 1 ( 3 months after birth)

Artificial infection by the method of subcutaneous and intravenous injection

\begin{tabular}{|l|c|}
\hline Temperature & 41.5 \\
\hline Erythrocytes & 610 \\
\hline $\begin{array}{c}\text { Varieties of R. (Type I } \\
\text { (in 1.000 } \\
\text { Erythrocytes) }\end{array}$ & 2 \\
Type II & 6 \\
Type III & 8 \\
\hline Haemoglobin & 46 \\
\hline Leucocytes & 20.300 \\
\hline
\end{tabular}

Case 2 (3 months after birth)

Artificial injection similar to case 1

\begin{tabular}{|l|c|}
\hline Temperature & 41.3 \\
\hline Erythrocytes & 690 \\
\hline Varieties of R. \begin{tabular}{c|c|} 
Type I \\
(in 1.000 \\
Type II \\
Type II
\end{tabular} & $\begin{array}{l}4 \\
\text { Erythrocytes) }\end{array}$ \\
\hline Haemoglobin & 52 \\
\hline Leucocytes & 28.000 \\
\hline
\end{tabular}

In short, the histological changes regarding the reticulocytes in blood-stream of swine affected with both diseases were not same as those in hog cholera.

In the two diseases, the counts of such cells constantly increased in the course of high fever. Moreover, total red bloodcorpuscles decreased in cases of swine plague, but no change demonstrated in swine erysipelas.

Therefore, the results of comparative observations on the counts of red blood-corpuscles in circulating blood of swine affected with one of the three diseases are simply tabulated as follows :

'The results of our studies on numerical changes of red bloodstream of swine in different conditions are briefly summarized as follows : 


\begin{tabular}{|l|c|c|c|}
\hline & Hog cholera & Swine plague & Swine erysipelas \\
\hline $\begin{array}{c}\text { Erythrocytes } \\
\text { with } \\
\text { the S. G. F. }\end{array}$ & $\begin{array}{l}\text { decreased or } \\
\text { disappeared }\end{array}$ & $\begin{array}{c}\text { increased or } \\
\text { no change }\end{array}$ & $\begin{array}{l}\text { increased or } \\
\text { no change }\end{array}$ \\
\hline Erythrocytes & decreased & decreased & no change \\
\hline
\end{tabular}

\section{SUMMARY}

1. The reticulocytes are demostrated in blood-stream of healthy swine and the counts different according to ages, higher in young animals but lower in the older. Their proportion to all red blood-corpuscles in blood-stream is $0.2-4.0 \%$, varying for a period of $3-20$ months after birth.

2. In circulationg blood of swine affected with hog cholera, numerical changes of reticulocytes are noticeably affected in the course of the disease. A gradual decrease of the cells is constantly demonstrated until an attack of fever, but they were rare or absent in blood-stream after the appearance of characteristic symptoms.

Of course, the counts of whole red blood-cells are also reduced in the disease.

3. On the other hand, in case of recovery from the disease, counts of reticulocytes in circulating blood is demonstrated higher than those before the injection of the virus.

4. Three types of reticulocytes are differentiated by the shape and the situation of stained granules; the Type I and Type II disappear earlier from the blood-strean, when the swine affected with hog cholera are feverish. Moreover, these two types also reappear in circulating blood earlier than the Type III, when the animals recovered from the disease.

5. The swine which receive the injection of an weakly attenuated virus, usually showed the same numerical changes of reticulocytes in circulating blood as in the swine affected with hog cholera.

6. In cases of swine plague and swine erysipelas, no diminution of reticulocytes is found in blood-stream, but the counts are higher, even in feverish condition. 
Therefore, on the basis of the numerical change of reticulocytes in circulating blood, hog cholera may also be differentiated from cases of swine plague or swine erysipelas.

7. Judging from the histological changes in blood-stream of the swine affected with hog cholera, the diminution of erythrocytes in the disease may be reasonably considered as a result of a temporary aplastic anaemia.

The authors wish to acknowledge their indebtedness to Dr. N. Nakamura for his helpful advice during this study and his kind revision of the paper.

\section{REFERENCES}

1. Natscheff, B. : Wien. T. Mschr. No. 9, 1931.

2. Grawitz: Kl. Patholog. d. Blutes. 1911.

3. Hertz: Fol. Hamatholog. Vol. 9, 1910.

4. Saito: Keio Igahu. Vol, 1, No. 1.

5. Nishitani : Nippon Biseibutsugakkai Zassi, Vol, 19, No, 2.

6. Imanishi : Kyolo Ikadaigaku Zassi, Vol. 3, No. 4.

7. Iketani : Tokyo Igakkai Zassi, Vol. 41, No. 7.

8. Sugiyama: Osaka Igakkai Zassi, Vol. 30, No. 8.

9. Sakurai :

10. Tahara :

11. Horie: Manshu Igakkai Zassi, Vol. 8, No. I.

12. Talezuka: Nipron Naikagakkai Zassi, Vol. 16, No. 2.

\section{EXPILANATION OF PLATES}

Fig. 1. a. $\ldots \ldots \ldots$ Type I

c......... Type II show the varieties of reticulocyte in the red blood-

Fig. 2, b........ Type III corpuscles of swine.

\section{豚これらノ血球變化 (第 1 報)}

赤血球特ニンノ網狀物質二就于

石井進渡邊昇藏三浦勇治

(農林者獸疫調查所)

（昭 和 10 年 2 月 18 日受附)

家盲ノ赤血球內 =存ス儿超生體染色性物質二就キテ研究七シ學者八僅 = 
Natscheff Bojan (1931) ノミナリ。同氏八馬，牛，緬羊，豚，犬，猫，家鬼 ニツキ健康體二於テハ如何ナル割合二流血赤血球內二本物質ガ存在スルヤ

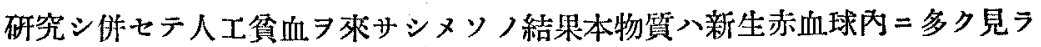
ル、所見习指摘シ以テ再生䝷血二於テ多數流血中=移行スルモノナリトノ結 諭ヨ下七リ。而シテ本物質ノ何物ナルヤ二就キテハ今日多數議諭ノ存スル所 ナリトス余等八該物資ガ豚これら=於テ如何 $=$ 流血赤血球內 $=$ 消舆スルカ 7

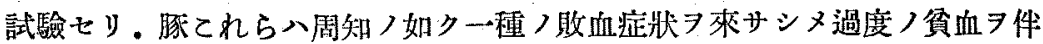
フ場合多キヨ以テ本物質卜ノ關係八實驗的二モ理論的二モ興味アリト考へ夕 レバナリ. 即チ得タ几實驗成績 7 示ス = (1) 健康豚生後 3 ケ月以後二於テ 八流血赤血球ノ $0.2-4.0 \%$ ，割合二本物質 含有スル赤血球存在ス. 而シテ コノ比率八年齢ノ增加スルト共二減少スル傾问アリ（2）豚とれら二於テハ 發病卜併行シ本物貨含有赤血球八次第 $=$ 流血球中ヨリ減少シ病ノ極期 $=$ 近ズ クニ從ヒ全ク流血赤血球ヨリソノ存在 㙓分利シ次第 $=$ 經過スル 移行ス.（3）而シテュ／減少乃至消散期＝於テハ最初第 1 型並第 2 型ガ減 少シ初メ第 3 型八永ク殘留シ次デ消失ス，更二爇分利後本物質会有赤血球發 生期=於テハ第 1 型並第 2 型早ク出現シ少シ掘レテ第 3 型ノ存在 7 流血中

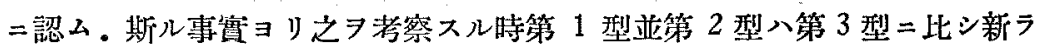
シキ新生赤血球ナリト云フラ得ベシ. 實際再生筫血二於テ八第 1 型並第 2 型共二多數存在入，第 3 型八同稼再生貧血 =多數所見スト踓モ又貧血進行期 =モ比較的多ク殘存スル所見 7 肯定シ得へシ.(4) 豚てれら豫防液接種後=

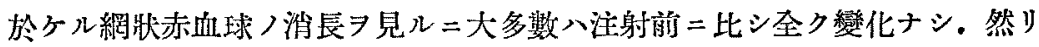
ト踓モ 1 例二於テ爇荻ニハ到ラザリシトハ踓本細胞ノ減少並二消失ヨ所見シ タリ. 斯ル所見 7 推理スルニ之豚てれら豫防液つ減毒不充分ナリシ結果ナラ

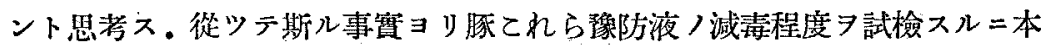

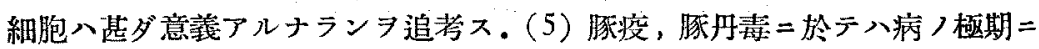
於デララ本物質 $ヨ$ 依然多數赤血球內二證明存在ス. 從ツテ本物質ノ流血赤血 球ニ於ヶル檢出八豚てれら類症鑑別上意義アルモノト信ズ. 更二赤血球數二

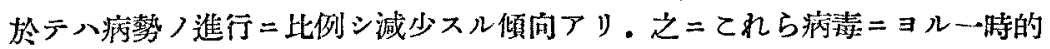

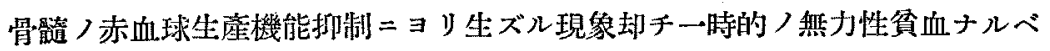




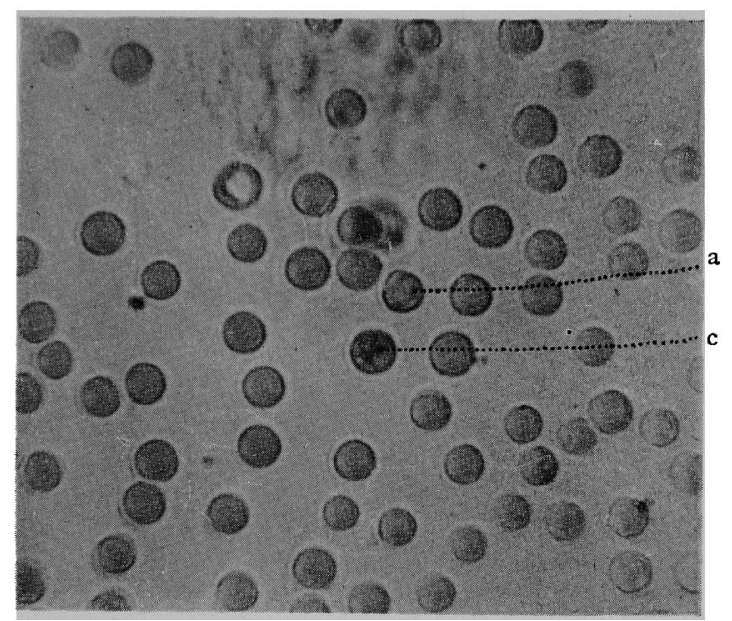

Fig 1

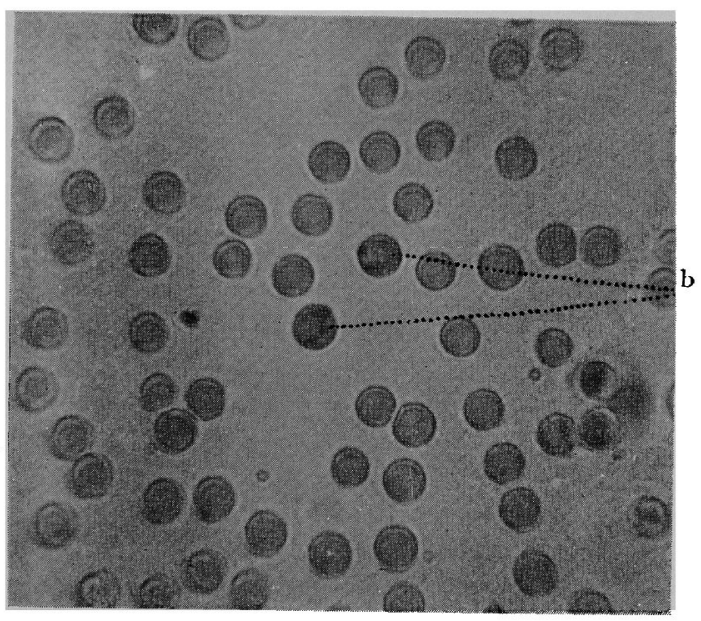

Fig 2 